\title{
A cross-sectional study among detergent workers exposed to liquid detergent enzymes
}

F G B G J van Rooy, R Houba, N Palmen, M M Zengeni, I Sander, J Spithoven, J $M$ Rooyackers and D J J Heederik

Occup. Environ. Med. 2009;66;759-765; originally published online 16 Aug 2009; doi:10.1136/oem.2008.045245

Updated information and services can be found at:

http://oem.bmj.com/cgi/content/full/66/11/759

\section{These include:}

References This article cites 29 articles, 13 of which can be accessed free at: http://oem.bmj.com/cgi/content/full/66/11/759\#BIBL

Rapid responses You can respond to this article at:

http://oem.bmj.com/cgi/eletter-submit/66/11/759

Email alerting Receive free email alerts when new articles cite this article - sign up in the box at service the top right corner of the article

Topic collections Articles on similar topics can be found in the following collections

\section{Notes}




\title{
A cross-sectional study among detergent workers exposed to liquid detergent enzymes
}

\author{
F G B G J van Rooy, ${ }^{1,2,3}$ R Houba, ${ }^{1}$ N Palmen, ${ }^{4}$ M M Zengeni, ${ }^{1,2}$ I Sander, ${ }^{5}$ J Spithoven, ${ }^{2}$ \\ J M Rooyackers, ${ }^{1,6}$ D J J Heederik ${ }^{2,7}$
}

${ }^{1}$ Netherlands Expertise Centre for Occupational Respiratory Disorders, Utrecht, The Netherlands; ${ }^{2}$ Division Environmental Epidemiology, Utrecht University, Utrecht, The Netherlands; ${ }^{3}$ Arbo Unie Expert Centre for Chemical Risk Management, Utrecht, The Netherlands; ${ }^{4}$ Encare Arbozorg, Maastricht, The Netherlands;

${ }^{5}$ BGFA - Research Institute of Occupational Medicine, Institute of the Ruhr University of

Bochum, Bochum, Germany;

${ }^{6}$ Division Heart and Lungs,

University Medical Centre

Utrecht, Utrecht, The

Netherlands: ${ }^{7}$ Julius Centre for

Health Sciences and Primary

Care, University Medical Centre

Utrecht, Utrecht, The

Netherlands

Correspondence to:

Frits van Rooy, Division

Environmental Epidemiology,

Institute for Risk Assessment

Sciences, P.O. Box 80.178,

NL-3508 TD Utrecht, The

Netherlands; f.vanrooy@uu.nl

Accepted 13 May 2009

Published Online First

16 August 2009

\section{ABSTRACT}

Objectives: To investigate sensitisation and respiratory health among workers who produce liquid detergent products and handle liquid detergent enzymes.

Methods: We performed a cross-sectional study among 109 eligible workers of a detergent products plant. 108 were interviewed for respiratory and allergic symptoms and 106 blood samples were taken from them to examine sensitisation to enzymes. Those sensitised to $\geqslant 1$ enzymes were referred for clinical evaluation. Workers and representatives were interviewed to characterise exposure qualitatively and estimate exposure semiquantitatively. Workers were classified into three exposure groups with varying exposure profiles to enzymes, based on frequency, duration, and level of exposure.

Results: Workers were exposed to proteases, $\alpha$-amylase, lipase and cellulase. The highest exposures occurred in the mixing area. Liquid spills with concentrated enzyme preparations and leakage of enzymes during weighing, transportation and filling were causing workplace contaminations and subsequently leading to both dermal and inhalation exposure for workers.

Workers with the highest exposures reported significantly more work-related symptoms of itching nose (prevalence ratio $(\mathrm{PR})=4.2,95 \% \mathrm{Cl} 1.5$ to 12.0 ) and sneezing $(\mathrm{PR}=4.0,95 \% \mathrm{Cl} 1.5$ to 10.8$)$ and marginally significant more symptoms of wheezing $(\mathrm{PR}=2.9,95 \% \mathrm{Cl} 0.9$ to 8.7) compared with the least exposed group.

Fifteen workers (14.2\%) were sensitised to $\geqslant 1$ enzymes. A marginally statistically significant gradient in sensitisation across the exposure categories was found $(p=0.09)$. There was a clinical case of occupational asthma and two others with probable occupational rhinitis.

Conclusions: Workers exposed to liquid detergent enzymes are at risk of developing sensitisation (14\%) and respiratory allergy.

Occupational asthma $(\mathrm{OA})$ in the detergent industry was first reported in 1969 and associated with exposure to dust of proteolytic enzymes. ${ }^{12}$ Occupational allergies were considered to be under control as a result of encapsulation of enzymes and improved hygiene in the $1970 s^{34}$ and evidence exists for a reduction of OA risk. ${ }^{5}{ }^{6}$ Despite these measures, sensitisation could not be totally prevented $^{4}$ and new outbreaks of OA have been reported due to detergent enzymes exposure. ${ }^{78}$

This study was occasioned by the occupational health service of a liquid detergent production plant which, in a pilot study, reported that three out of 12 highly exposed workers were sensitised to detergent protease (Savinase).

\section{What this paper adds}

- Occupational allergies have been reported due to detergent enzymes exposure.

- No occupational respiratory allergies have been reported in detergent production industries related to liquid detergent enzymes.

- The aim of this study was to investigate sensitisation among workers handling liquid detergent enzymes, and the respiratory health among sensitised workers.

- Exposure to liquid detergent enzymes should be regarded as an occupational risk leading to airway symptoms, sensitisation and occupational allergy.

- Exposure to liquid detergent enzymes should be minimised, health surveillance should be offered to exposed workers and development of noncommercial validated immunoassays for specific enzyme allergens is warranted for screening and monitoring purposes.

As far as we know, no occupational respiratory allergies have been reported in detergent production industries related to liquid detergent enzymes. The novelty of the present study is that it was conducted in a detergent plant producing liquid detergents using only liquid enzymes. The plant never produced powdered detergent products and neither used powdered nor encapsulated enzymes. This study was conducted among all workers in the plant who were potentially exposed to liquid detergent enzymes. The first aim of this study was to investigate sensitisation among workers handling liquid detergent enzymes and secondly, the respiratory health among sensitised workers.

\section{MATERIAL AND METHODS}

\section{Study design, setting and participants}

In March 2006 we conducted a cross-sectional study among 109 eligible workers who were potentially exposed to liquid detergent enzymes in a plant producing liquid detergents. We obtained written, informed consent from 108 (99\%) workers who completed the questionnaire. From 106 (97\%), blood samples were taken. One worker refused for personal reasons to participate in the study and two other workers who completed the questionnaire refused to provide a blood sample.

Before 1992 the plant produced several liquidbased but enzyme-free, detergents and cleaning products such as shampoo, liquid abrasives and washing-up liquid. Liquid enzymes were first 
introduced around 1992 to improve the cleaning power of the liquid detergents. Granulated enzymes have never been used in this company.

The plant produces only liquid detergents (SD 60.000 metric tons in 2005) and uses proteases, amylases, lipase and cellulases (table 1) (totally $540883 \mathrm{~kg}$ in 2005). The production of detergents includes: (1) weighing and transporting ingredients to the tubs including concentrated liquid enzymes; (2) adding the ingredients to the tubs and mixing with water; and (3) filling of bottles. Several meetings were held to inform workers about the goal of the study.

\section{Exposures}

Historic exposure data were not available and exposure to enzymes at this point in time could not be measured because appropriate immune assays for these allergens were not available. As a consequence, a semi-quantitative exposure assessment was performed. We observed the workplace and interviewed workers and representatives to characterise current exposure to enzymes qualitatively and estimate exposure semiquantitatively. We identified all tasks with potential enzyme exposure and scored them by frequency, duration of exposure and enzyme concentration of the handled product. Both inhalation and dermal exposure were considered. Subsequently, we created several groups of workers with various levels of enzyme exposure based on this semiquantitative exposure assessment, by assigning all tasks to different job categories.

Exposure was assigned blindly to the workers' status of sensitisation. All workers were classified into three groups with, respectively, high, moderate and low exposure to enzymes. The high exposure group handled concentrated enzyme products and was potentially exposed during the entire working day. The moderate exposure group handled diluted enzyme products and exposure was limited to a few tasks during the working day. The low exposure group was only incidentally exposed to enzyme products.

Besides exposure to detergent enzymes some other potentially harmful exposures occurred. Some ingredients have been labelled as irritants (eg, perfumes and preservatives used in the detergents). Other sensitisers cannot be excluded in a few products (especially some preservatives), but compared to the liquid enzymes, the amounts used are low and these substances have been reviewed as potential causes of sensitisation in individual clinical cases.

\section{Questionnaire}

Participants completed a self-administered standardised questionnaire supplemented with questions about respiratory, mucous membrane, atopic symptoms and work history. The questionnaire was based on items described in the detergent industry ${ }^{9}$ and some of the questionnaire items were taken from the European Community Respiratory Health Survey (ECRHS).

\section{Serology}

We assessed total serum IgE and specific IgE reactions to a panel of common environmental allergens (house dust mites, cat, dog, grass and birch pollen)..$^{10}$ A total IgE of $>100 \mathrm{kU} / \mathrm{l}$ and/or at least one positive reaction to common allergens was defined as atopy. For some of the enzymes no validated serology tests were available and therefore two different approaches were taken to assess sensitisation. First, by a low-cost "in-house" developed enzyme immunoassay and second, by a customised ImmunoCAP system at the German Social Accident Insurance (BGFA), Institute of the Ruhr University of Bochum in Germany.

For the in-house assay all liquid enzyme solutions, except Carezyme and Endolase, were dialysed against PBS using dialysis hoses 8000 MWCO (Spectrapor Cat. No. 132131) (Spectrum Laboratories Inc., Rancho Dominguez, California, USA) to remove low molecular weight additives. The dialysed supernatants were harvested and stored at $-20^{\circ} \mathrm{C}$. A microtitreplate-based enzyme-linked immunoassay was applied, using a polyclonal rabbit anti-human IgE/swine anti-rabbithorseradish peroxidase IgE detection system. The optical density was used as readout relative to blank samples where levels more than four times the standard deviation were considered as positive.

\section{ImmunoCAP system}

Specific IgE to the enzymes was measured using Streptavidin ImmunoCAPs and fluorescent enzyme immunoassay on an ImmunoCAP 250 system (Phadia, Uppsala, Sweden) as described previously. ${ }^{11}$ All enzymes were biotinylated with a

Table 1 Characteristics and amount of enzymes used in liquid detergent production and the number of sensitised workers per enzyme

\begin{tabular}{cllcc}
\hline & Enzymes & Bacterial/fungal & $\begin{array}{l}\text { Kilogrammes used in } \\
\mathbf{2 0 0 5}\end{array}$ & $\begin{array}{l}\text { Number of sensitised } \\
\text { workers }\end{array}$ \\
\hline Proteases: & Alcalase 2.5 I & Bacterial & 112.595 & 5 \\
a & Alcalase ultra & Bacterial & 19.564 & 5 \\
b & Purafect & Bacterial & $224.586^{*}$ & 4 \\
c & Savinase & Bacterial & 10.150 & 4 \\
d & Everlase & Bacterial & $*$ & 4 \\
e & & & & 13 \\
$\alpha$-Amylases: & Purastar & Bacterial & 30.802 & 13 \\
f & Termamyl & Bacterial & 135.735 & 8 \\
g & Stainzyme & Bacterial & $<200$ & 1 \\
h & & & & \\
Lipase: & Lipex 100 I & Fungal & $<100$ & 4 \\
i & Carezyme & Fungal & 5.055 & 2 \\
Cellulases: & Endolase & Fungal & 2.096 & \\
j & & & & \\
k & & & & \\
\hline
\end{tabular}

${ }^{*}$ Total kilogrammes of Purafect and Everlase. 
fivefold molar excess of D-biotinoyl- $\varepsilon$-aminocaproic acid $\mathrm{N}$ hydroxysuccinimide ester (NHS-Biotin) in $10 \mathrm{mM}$ carbonate buffer ( $\mathrm{pH}$ 8.5), after estimating protein concentration (Bradford assay, Biorad, München, Germany) and the average molecular weight of each enzyme preparation by SDS-PAGE using pre-casted NuPAGE gels (Novex, San Diego, California, USA). For a first screening, mixtures of biotinylated enzymes with similar function and protein pattern (each with an $\mathrm{OD}_{280}$ of 1.5) were bound to Streptavidin ImmunoCAPs and tested: $\alpha$-amylases (Purastar, Termamyl, Stainzyme), cellulases (Carezyme, Endolase), Alcalases (Alcalase 2.51 , Alcalase ultra 2.51 ), and Subtilisins (Purafect, Savinase, Everlase). Single enzymes were then bound $\left(\mathrm{OD}_{280}\right.$ of 1.5$)$ and tested: with Lipex 1001 all sera, with the other enzymes only sera which had been positive in the first screening with the respective mixture were measured.

Streptavidin ImmunoCAPs with $\boldsymbol{\alpha}$-amylases had been incubated in acidic buffer $\left(50 \mathrm{mM}\right.$ citric acid, $50 \mathrm{mM} \mathrm{Na}_{2} \mathrm{HPO}_{4}, \mathrm{pH}$ 4.2) for $1 \mathrm{~h}$ at $50^{\circ} \mathrm{C}$ and washed extensively before measurements to abolish unspecific reactions in fluorescent enzyme immunoassay.

Values $\geqslant 0.35 \mathrm{kU} / 1$ were defined positive, indicating sensitisation.

Because a validated test system is not yet available, workers who were positive in the in-house assay or the ImmunoCAP system were considered sensitised to detergent enzymes.

\section{Clinical evaluation}

Workers sensitised to $\geqslant 1$ enzymes underwent further clinical investigation including clinical history-taking, nasal examination, spirometry and assessment of non-specific bronchial hyperresponsiveness (NSBH) to histamine within $24 \mathrm{~h}$ after exposure after a continuous period of working of at least 2 weeks.

A diagnosis of $O A$ was excluded if there were no indications of asthma in the medical history and a worker showed no NSBH within $24 \mathrm{~h}$ after exposure while working uninterrupted for 2 weeks. $^{12} 13$

Spirometry was obtained by experienced technicians according to European Respiratory Society standards ${ }^{14}$ by using a pneumotachograph with specific software (Pneumotachograph and 4.66 software, Jaeger; Würzburg, Germany). Histamine was administered during a controlled inspiratory capacity breathing dosimeter technique using the Aerosol Provocation System with a Medic-Aid nebulizer (Jaeger; Würzburg, Germany), starting with diluent and followed by doubling doses of histamine from $0.026 \mathrm{mg}$ to a maximum dose of $2.5 \mathrm{mg}$. The test was stopped when a fall of $20 \%$ in forced expiratory volume in 1 second $\left(\mathrm{FEV}_{1}\right)$ was observed (PD20) or the maximum cumulative dose was reached. If necessary, bronchoconstriction was treated with inhalation of salbutamol. ${ }^{15}$

All workers with NSBH when at work performed serial peak expiratory flow rate (SPEFR) measurements during 2 weeks at work and 2 weeks away from work after which histamine challenge with assessment of NSBH was repeated. A change of one doubling dose increase in PD20 was regarded as significant. SPEFR measurements were interpreted using direct visual analysis by a panel of two experienced physicians. A diurnal variation in PEFRs of $\geqslant 20 \%$ was considered as diagnostic criterion. ${ }^{16}$ The diagnosis of work-related asthma was based on the American College of Chest Physicians (ACCP) consensus statement. ${ }^{16}$

The medical diagnosis of OA was based on four criteria according to the ACCP: (1) diagnosis of asthma; (2) onset of asthma after entering the workplace; (3) association between symptoms of asthma and work; and (4) one or more of the following criteria: (4a) workplace exposure to an agent known to give rise to $\mathrm{OA}$; (4b) work-related changes in $\mathrm{FEV}_{1}$ or PEFR; or (4c) work-related changes in bronchial responsiveness. ${ }^{17}$ The diagnosis of work-related rhinitis was based on a position paper of the EAACI Task force on Occupational Rhinitis. A suggestive clinical history of occupational rhinitis associated with sensitisation to detergent enzymes was considered as probable occupational rhinitis. ${ }^{18}$

\section{Epidemiological and statistical analysis}

All statistical analyses were performed using SAS software (SAS System for Windows version 9.1, SAS Institute, Cary, North Carolina, USA). Questionnaire data for 108 workers and serological data of 106 workers were used to compare the prevalence of respiratory symptoms and sensitisation between different exposure groups within the study population using low exposed workers as an internal reference group. We calculated prevalence ratios (PRs) and $95 \%$ CI by log-binomial regression analysis. ${ }^{19}$ A starting value of -4 for the intercept was used to prevent convergence problems. ${ }^{20} \mathrm{PRs}$ were adjusted for age and smoking habits (pack-years). The trend in sensitisation was investigated by logistic regression analysis (PROC LOGISTIC) by entering exposure group $(1,2,3)$ as a continuous variable in the regression model using the Wald $\chi^{2}$ test. We calculated the phi coefficient as a measure of the degree of association between the outcomes of the two different serology tests. Two-sided $p$ values of $\leqslant 0.05$ were considered to represent associations unlikely to be due to chance. For internal comparisons among small subgroups, we examined marginally significant $p$ values of $\leqslant 0.1$.

\section{RESULTS}

\section{Participants}

In table 2 the personal characteristics of the detergent workers are given, including the median years of employment and the number of workers in the exposure groups.

\section{Exposure assessment}

The highest exposure to liquid detergent enzymes occurred in the mixing area. Spills and leakages of enzymes during weighing, transporting and filling of the tubs were sources of

Table 2 Characteristics of 108 detergent workers

\begin{tabular}{ll}
\hline Characteristic & Number \\
\hline Sex & \\
$\quad$ Male (\%) & $88(81.5)$ \\
Age, years & \\
$\quad$ Mean (SD) & $40(7.9)$ \\
$\quad$ Range & $24-60$ \\
Smoking status (\%) & \\
$\quad$ Current smoker & $54(50.0)$ \\
$\quad$ Former smoker & $23(21.3)$ \\
$\quad$ Never smoked & $31(28.7)$ \\
Duration of employment (years) & \\
$\quad$ Median & 8.0 \\
$\quad$ Range & $1-34$ \\
Exposure group & \\
1. Low (\%) & $54(50.0)$ \\
2. Moderate (\%) & $37(34.3)$ \\
3. High (\%) & $17(15.7)$ \\
\hline
\end{tabular}


potential workplace contamination with high concentrated enzyme preparations, and workers were exposed via skin (splashes) and inhalation (aerosols). In addition, high-pressure cleaning of the floor and machines generated inhalable aerosols likely to contain enzymes.

Changing products on the production lines was the most important activity in the filling area, leading to spills and leakages of product containing enzymes in the workplace. Workers were potentially both directly exposed to the product (skin) and via aerosols (inhalation). Cleaning with high pressure (air) was also a possible source of inhalable aerosols containing diluted enzymes. Respirators were not used both in the mixing and in the filling area and workers often wore short sleeves.

\section{Symptoms and sensitisation}

Of 108 workers, 5 (5\%) reported having constantly problems with breathing, 2 of them (40\%) were sensitised to detergent enzymes, $14(13 \%)$ reported wheezing, 5/13 (39\%) were sensitised to detergent enzymes, 27 (25\%) reported to have an allergy including hay fever, 7 of them (26\%) were sensitised to detergent enzymes, 15 (14\%) reported work-related symptoms of an itching nose, 4 of them (27\%) were sensitised to detergent enzymes, and $17(16 \%)$ reported work-related sneezing, 5 of them (29\%) were sensitised to detergent enzymes. Symptoms were significantly more prevalent in the high exposure group than in the low exposure group. Workers in the high exposure group reported significantly more work-related symptoms of an itching nose $(\mathrm{PR}=4.2,95 \% \mathrm{CI} 1.5$ to 12.0$)$ and sneezing (PR $=4.0,95 \%$ CI 1.5 to 10.8$)$ (table 3$)$. The PR associated with wheezing was marginally significant at 2.9 (95\% CI 0.9 to 8.7$)$.

Of 106 workers, 15 (14\%) were sensitised to $\geqslant 1$ enzymes, mainly to bacterial $\alpha$-amylases and proteases (table 1). The agreement between the two different assay methods was very good (phi coefficient $=0.83$ ).

Thirty-eight workers (36\%) were atopic. None of the sensitised workers had previously worked in another (related) industry with exposure to enzymes. Of workers who were sensitised, 11 (73\%) were atopic and 8 (53.3\%) were current smokers. The median of years of employment was 8.0 years (range 1-20) which was not associated with sensitisation ( $\mathrm{PR}=0.96,95 \%$ CI 0.89 to 1.04$)$. Atopics were 4.9 times more likely to be sensitised to detergent enzymes than non-atopics $(\mathrm{PR}=4.92,95 \%$ CI 1.68 to 14.39). Sensitisation was not associated with smoking ( $\mathrm{PR}=0.99,95 \% \mathrm{CI} 0.95$ to 1.03 ).

A linear trend test showed a marginally significant $(p=0.09)$ gradient in sensitisation across the exposure categories (table 3 ).

Workers in the high exposure group were 2.8 times (marginally significant, $p=0.08$ ) more likely to be sensitised to detergent enzymes than workers in the low exposure group (table 3).

Five workers reported to have changed their employment within the plant from the high to the low exposure group and four workers from the moderate moved to the low exposure group. Of these nine workers, two workers reported to have changed job during their employment at this plant as a result of work-related symptoms. One of them was case 5 (table 4) and the other was not sensitised.

An additional analysis was conducted with workers classified according to the highest exposure group they had ever worked in. Workers in the high exposure group were 3.8 times (significant, $\mathrm{p}<0.05$ ) more likely sensitised to detergent enzymes than workers in the low exposure group (table 3 ).

\section{Clinical investigation}

Fifteen sensitised workers underwent further clinical investigations (table 4). All cases except case 15 had lung function values within normal range. NSBH was assessed in 12 cases of whom five (42\%) showed NSBH while at work (table 4). In case 1 it was impossible to assess NSBH for technical reasons, case 9 was on sick leave and in case $15 \mathrm{FEV}_{1}$ was too low ( $\leqslant$ predicted -3 SD). Six out of 15 cases (40\%) had work-related respiratory symptoms. Four cases of asthma were found of whom one was work-related. Case 5 was treated for asthma and had no workrelated symptoms. Case 12 met the criteria for OA. Case 15 was a smoker with inadequately treated asthma and persistent airway obstruction. He was strongly suspected of having occupational rhinitis and OA but did not finish the diagnostic work-up, so an occupational allergy could not be confirmed.

Three cases were diagnosed as rhinitis and two of them as work-related. Case 10 had pre-existing allergic rhinitis (hay fever) and although sensitised to workplace agents only experienced work-related symptoms when also having seasonal symptoms. Cases 13 and 14 had probable occupational rhinitis. Case 13 had childhood asthma, and pre-existing allergic rhinitis. Although he was sensitised to detergent enzymes, he claimed that parmatol and/or acticide (containing ethylisothiazolinone) was the cause of his work-related upper airway symptoms.

Thus, at least three cases $(12,13,14)$ out of 106 were diagnosed as having an (probable) occupational allergy.

\section{DISCUSSION}

This study shows that working in the liquid detergent production industry is associated with sensitisation to liquid detergent enzymes and likely with occupational respiratory allergies. The prevalence of sensitisation was $14.2 \%$ and at least three cases of (probable) occupational airway allergy were clinically confirmed. Workers were exposed to liquid detergent enzymes and specific tasks could be identified during which exposure was relatively high. All exposed workers were at risk for sensitisation but there appeared to be a trend towards a relatively increased number of sensitised workers with higher exposures. In addition, high exposed workers had significantly more upper airway symptoms and marginally significant lower airway symptoms compared with low exposed workers.

\section{Study limitations}

The study population was small, and this limited statistical power in internal comparisons, especially after adjusting for confounding variables in multiple regression modelling.

Two women were classified as low exposed, 18 as moderate and none as high, limiting the possibility to adjust for gender. However, patterns were similar in the whole population as in men only.

The in-house assay made use of the liquid enzyme solutions from the detergent industry. These were utilised without purification of the products used. Therefore, theoretically, sensitisation to possible contaminants cannot be excluded.

Information was collected in a standard manner and exposure was assigned blind to the serology test results. As a result, misclassification will likely be non-differential and exposureresponse relationships might have been underestimated.

The healthy worker effect is a potential source of bias in cross-sectional studies when restricted to actively employed workers. Leaving employment or job transfer to lower exposure as a result of disease may have led to underestimation of the effects of exposure. ${ }^{21}{ }^{22}$ According to the additional analysis job 
Table 3 Prevalence (\%) and adjusted prevalence ratios (PRs) with $95 \% \mathrm{Cl}$ of respiratory symptoms in exposure groups compared with an internal reference group (low exposed) and sensitisation

\begin{tabular}{|c|c|c|c|c|c|}
\hline \multirow[b]{3}{*}{ Exposure group } & \multirow{3}{*}{$\begin{array}{l}\text { Low } \\
(n=54) \\
(\%)\end{array}$} & \multirow{2}{*}{\multicolumn{2}{|c|}{$\begin{array}{l}\text { Moderate } \\
(\mathrm{n}=37)\end{array}$}} & \multirow{2}{*}{\multicolumn{2}{|c|}{$\begin{array}{l}\text { High } \\
(n=17)\end{array}$}} \\
\hline & & & & & \\
\hline & & $(\%)$ & PR $(95 \% \mathrm{Cl})$ & $(\%)$ & PR (95\% Cl) \\
\hline \multicolumn{6}{|l|}{ Symptoms } \\
\hline \multicolumn{6}{|l|}{ Trouble with breathing } \\
\hline Ever & $10(18.5)$ & $8(21.6)$ & 1.1 (0.5 to 2.6$)$ & $5(29.4)$ & $1.4(0.6$ to 3.6$)$ \\
\hline Repeatedly & $4(7.4)$ & $7(18.9)$ & $2.5(0.8$ to 8.1$)$ & $3(17.7)$ & $2.3(0.6$ to 9.1$)$ \\
\hline Cough last year & $7(13.0)$ & $3(8.1)$ & $0.5(0.1$ to 2.0$)$ & $2(11.8)$ & $0.7(0.2$ to 2.9$)$ \\
\hline \multicolumn{6}{|l|}{ SOB and wheezing (last year) } \\
\hline SOB & $8(14.8)$ & $2(5.4)$ & $0.3(0.1$ to 1.3$)$ & $0(0.0)$ & $-(-)$ \\
\hline Exercise-induced SOB & $6(11.1)$ & $3(8.1)$ & $0.6(0.1$ to 2.4$)$ & $0(0.0)$ & $-(-)$ \\
\hline Wheezing & $5(9.3)$ & $4(10.8)$ & $1.1(0.3$ to 3.8$)$ & $5(29.4)$ & $2.9(0.9$ to 8.7$) \dagger$ \\
\hline \multicolumn{6}{|l|}{ Asthma } \\
\hline Asthma attack last year & $3(5.6)$ & $2(5.4)$ & 0.7 (0.1 to 4.5$)$ & $0(0.0)$ & $-(-)$ \\
\hline Asthma attack, doctor diagnosed & $2(3.7)$ & $1(2.7)$ & $0.5(0.0$ to 6.4$)$ & $2(11.8)$ & $2.9(0.5$ to 18.1$)$ \\
\hline \multicolumn{6}{|l|}{ Allergies } \\
\hline Allergy (including hay fever) & $17(31.5)$ & $6(16.2)$ & $0.6(0.3$ to 1.3$)$ & $4(23.5)$ & $0.9(0.3$ to 2.1$)$ \\
\hline Doctor visit last year due to allergic symptoms & $5(9.3)$ & $4(10.8)$ & $1.2(0.1$ to 9.2$)$ & $3(17.7)$ & $2.3(0.3$ to 16.3$)$ \\
\hline \multicolumn{6}{|l|}{ Work-related respiratory symptoms (last year) } \\
\hline $\mathrm{SOB}$ & $3(5.6)$ & $1(2.7)$ & $0.5(0.0$ to 4.3$)$ & $0(0.0)$ & $-(-)$ \\
\hline Chest tightness & $1(1.9)$ & $3(8.1)$ & $4.3(0.5$ to 40.6$)$ & $1(5.9)$ & 2.7 (0.2 to 41.0$)$ \\
\hline Cough symptoms & $5(9.3)$ & $3(8.1)$ & $0.8(0.2$ to 3.3$)$ & $2(11.8)$ & $1.0(0.2$ to 4.6$)$ \\
\hline Itching nose & $5(9.3)$ & $4(10.8)$ & $1.3(0.4$ to 4.5$)$ & $6(35.3)$ & $4.2(1.5 \text { to } 12.0)^{*}$ \\
\hline Sneezing & $6(11.1)$ & $4(10.8)$ & $1.1(0.3$ to 3.6$)$ & $7(41.2)$ & $4.0(1.5 \text { to } 10.8)^{*}$ \\
\hline \multicolumn{6}{|c|}{ Serology } \\
\hline Sensitised to $\geqslant 1$ common allergen/total $\lg E>100 \mathrm{kU} / \mathrm{l}$ & $20(37.0)$ & $12(32.4)$ & $0.9(0.5$ to 1.7$)$ & $6(40.0) \dagger$ & $1.0(0.5$ to 2.1$)$ \\
\hline Sensitised to detergent enzymes $(\%)$ & $5(9.3)$ & $6(16.2)$ & $1.5(0.5$ to 4.9$)$ & $4(26.7) \ddagger$ & $2.8(0.9$ to 9.0$) \dagger$ \\
\hline $\begin{array}{l}\text { Sensitised to detergent enzymes (\%) highest exposure } \\
\text { ever }\end{array}$ & $3(6.7)$ & $7(17.5)$ & $2.4(0.6$ to 10.3$)$ & $5(23.8) \div$ & $3.8(1.0 \text { to } 14.1)^{*}$ \\
\hline
\end{tabular}

transfer may have led to an underestimation of exposureresponse relationships, although only two workers reported to have changed job during their employment at this plant as a result of work-related symptoms.

There was no evidence of confounding, either by smoking status or age.

\section{Symptoms and sensitisation}

Workers in the highest exposure group reported (marginally) significant more respiratory symptoms. The excess of symptoms in the high exposure group could not be explained by allergic reactions to enzymes only as we identified only three workers with clinically confirmed airway allergy. False negative serology test results may be an explanation. Irritant effects of detergent enzymes or exposure to other allergens or irritants may have induced symptoms as well. However, respiratory symptoms and allergy may develop through separate pathways as suggested by Skjold et al in their prospective cohort study among baker apprentices. They showed that the occurrence of new airway symptoms was not always paralleled by sensitisation to occupational allergens. ${ }^{23}$

In the present study the prevalence of sensitisation was $14 \%$ according to results of two different serology tests. When only one serology test had been used to estimate sensitisation, the prevalences would be $13 \%$ for the "in-house assay" and 11\% for the ImmunoCAP system, respectively. Workers were most often sensitised to bacterial $\alpha$-amylase probably due to the higher turnover for this bulk chemical. Cross-reactivity between some detergent enzymes may be possible, but earlier experiences indicate that enzymes have distinctly different epitopes. ${ }^{24}$

In the detergent industry a prevalence between 6.7 and $11.6 \%$ has been reported using a skin prick test method for Alcalase, Termamyl and Subtilisin B at a liquid detergent manufacturing site. These workers were also exposed to granulated detergents. ${ }^{25}$ The novelty of our study is that workers were exposed to liquid detergent enzymes only and never had been exposed to granulate detergents, indicating the occupational risk of exposure to liquid detergent enzymes for sensitisation.

Sensitised workers were found in every exposure group but a trend toward a relatively increased number of sensitisation with higher exposures is suggestive for an exposure-response effect. It is not clear when workers became sensitised as both data about the introduction of specific enzymes and exposure periods are lacking.

Atopy was significantly associated with sensitisation to enzymes and this is consistent with some but not all earlier findings. ${ }^{6}{ }^{26}$

\section{Clinical investigation}

A minority of sensitised workers showed NSBH while at work. A diagnosis of $\mathrm{OA}$ was excluded if there were no indications of asthma in the medical history and a worker showed no NSBH 


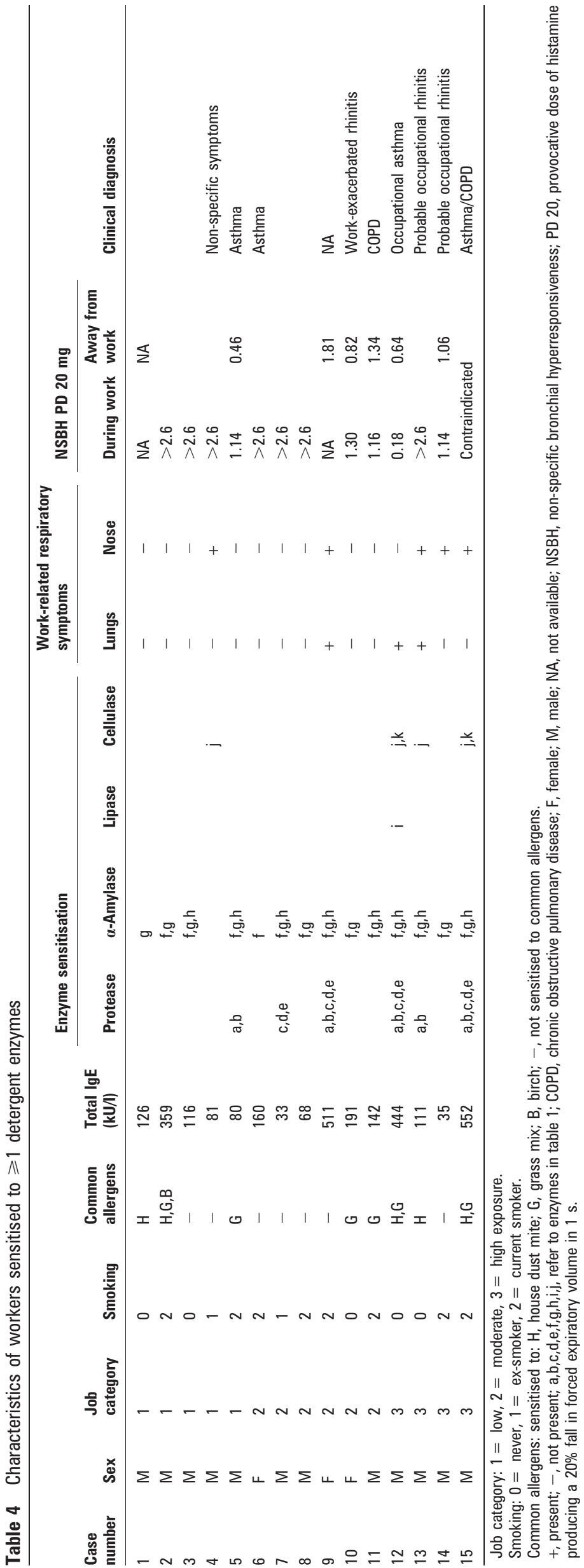

within $24 \mathrm{~h}$ after exposure while working uninterrupted for 2 weeks. ${ }^{12} 13$

According to Fishwick et al, ${ }^{27}$ a normal result from a test of NSBH is not sufficiently useful to exclude OA and as a result cases of OA will be missed. This is in contrast with Tarlo et al, who considered a methacholine challenge within $24 \mathrm{~h}$ after exposure as useful, having a high predictive value in excluding OA. ${ }^{12} 28$

Two cases of occupational allergy were clinically confirmed. The prevalence of occupational allergies is likely to be underestimated because in two sensitised workers with work-related symptoms the diagnostic work-up could not be completed.

One of these had asthma with a strong suspicion of an occupational allergy. He and the two workers who refused serology testing belonged to the high exposure group.

\section{Prevention}

The current production process was not designed to avoid contact with enzymes. Workers were not aware of the risk of exposure to liquid enzymes, so there was no trigger to avoid exposure at any level of the organisation within the plant. For example, high-pressure cleaning generated inhalable aerosols likely to contain enzymes and could have played a crucial role in becoming sensitised. This lack of exposure and risk awareness resulted in workers' exposure to liquid detergent enzymes and sensitisation to liquid detergent enzymes. Sensitisation is an essential step towards allergy and should be avoided. ${ }^{29}$ Most important problem-solving directions are to implement techni$\mathrm{cal}$ control measures to prevent the regular spills and leakages by enclosure and automation of the weighing, transporting and mixing process and enclosure of machineries during product changes. In addition, education and creation of awareness among workers about the health risks of exposure to enzymes and working in a more hygienic way should be initiated. Using high pressure for cleaning activities should definitely be banned, first of all by preventing process leakages and the subsequent cleaning activities. A health surveillance programme should especially be implemented when a "no observed adverse effect level" for detergent enzymes cannot be identified. The approach in this study can be seen as the first round of surveillance and is an example of a population-based approach leading to diagnosis in individuals. ${ }^{30}$

In conclusion, exposure to liquid detergent enzymes should be regarded as an occupational hazard leading to sensitisation and occupational allergy. To prevent sensitisation and airway allergies as a result of exposure to liquid detergent enzymes, exposure should be minimised and health surveillance should be offered to exposed workers. Development of non-commercial validated immunoassays for specific enzyme allergens in the liquid enzyme industry is warranted for screening and monitoring purposes.

Acknowledgements: The authors thank Mark Berendsen of Encare Arbozorg, Maastricht, The Netherlands for his assistance in the study and Dr Paul Cullinan, Department of Occupational and Environmental Medicine, National Heart and Lung Institute, Imperial College, London, UK, who reviewed the draft manuscript and provided helpful suggestions for improvements.

Funding: This study was supported by the company. A contract guaranteed independence of the research group according to criteria set by the Dutch Royal Academy of Sciences (KNAW) in close collaboration with the occupational health service.

Competing interests: None.

Patient consent: Obtained.

Provenance and peer review: Not commissioned; externally peer reviewed. 


\section{REFERENCES}

1. Flindt ML. Pulmonary disease due to inhalation of derivatives of Bacillus subtilis containing proteolytic enzyme. Lancet 1969;1:1177-81.

2. Pepys J, Longbottom JL, Hargreave FE, et al. Allergic reactions of the lungs to enzymes of Bacillus subtilis. Lancet 1969;1:1181-4.

3. Sarlo K, Clark ED, Ryan CA, et al. ELISA for human lgE antibody to subtilisin A (Alcalase): correlation with RAST and skin test results with occupationally exposed individuals. J Allergy Clin Immunol 1990;86:393-9.

4. Liss GM, Kominsky JR, Gallagher JS, et al. Failure of enzyme encapsulation to prevent sensitization of workers in the dry bleach industry. J Allergy Clin Immunol 1984;73:348-55

5. Cathcart M, Nicholson P, Roberts D, et al. Enzyme exposure, smoking and lung function in employees in the detergent industry over 20 years. Medical Subcommittee of the UK Soap and Detergent Industry Association. Occup Med 1997:47:473-8.

6. Juniper CP, How MJ, Goodwin BF, et al. Bacillus subtilis enzymes: a 7-year clinical, epidemiological and immunological study of an industrial allergen. J Soc Occup Med 1977;27:3-12.

7. Cullinan $\mathbf{P}$, Harris JM, Newman-Taylor AJ, et al. An outbreak of asthma in a modern detergent factory. Lancet 2000;356:1899-900.

8. Vanhanen $\mathbf{M}$, Tuomi T, Tiikkainen $U$, et al. Risk of enzyme allergy in the detergent industry. Occup Environ Med 2000;57:121-5.

9. Nicholson PJ, Newman Taylor AJ, Oliver P, et al. Current best practice for the health surveillance of enzyme workers in the soap and detergent industry. Occup Med 2001;51:81-92.

10. Doekes G, Douwes J, Wouters I, et al. Enzyme immunoassays for total and allergen specific IgE in population studies. Occup Environ Med 1996;53:63-70.

11. Sander I, Kespohl S, Merget R, et al. A new method to bind allergens for the measurement of specific IgE antibodies. Int Arch Allergy Immunol 2005;136:39-44.

12. Tarlo SM, Liss GM. Evidence based guidelines for the prevention, identification, and management of occupational asthma. Occup Environ Med 2005;62:288-9.

13. Tarlo SM, Boulet LP, Cartier A, et al. Canadian Thoracic Society guidelines for occupational asthma. Can Respir J 1998;5:289-300.

14. Quanjer PH, Tammeling GJ, Cotes JE, et al. Lung volumes and forced ventilatory flows: official statement of the European Respiratory Society. Eur Respir J 1993;6:5-40.

15. Sterk PJ, Fabbri LM, Quanjer PH, et al. Airway responsiveness. Standardized challenge testing with pharmacological, physical and sensitizing stimuli in adults. Report working party standardization of lung function tests, European community for steel and coal. Official statement of the European respiratory society. Eur Respir J Supp/ 1993;16:53-83.

16. Tarlo SM, Balmes J, Balkissoon R, et al. Diagnosis and management of work-related asthma: American College of Chest Physicians Consensus Statement. Chest 2008;134:1S-41S.

17. Chan-Yeung $\mathbf{M}$. Assessment of asthma in the workplace. ACCP consensus statement. American College of Chest Physicians. Chest 1995;108:1084-117.

18. EAACI Task Force on Occupational Rhinitis, Moscato G, Vandenplas O, et al. Occupational rhinitis. Allergy 2008;63:969-80.

19. Thompson ML, Myers JE, Kriebel D. Prevalence odds ratio or prevalence ratio in the analysis of cross sectional data: what is to be done? Occup Environ Med 1998;55:272-7.

20. Deddens JA, Petersen MR. Approaches for estimating prevalence ratios. Occup Environ Med 2008;65:501-6

21. Eisen EA. Healthy worker effect in morbidity studies. Med Lav 1995;86:125-38.

22. Eisen EA, Wegman DH, Louis TA, et al. Healthy worker effect in a longitudinal study of one-second forced expiratory volume (FEV1) and chronic exposure to granite dust. Int J Epidemiol 1995;24:1154-61.

23. Skjold T, Dahl R, Juhl B, et al. The incidence of respiratory symptoms and sensitisation in baker apprentices. Eur Respir J 2008;32:452-9.

24. Elms J, Robinson E, Mason $\mathrm{H}$, et al. Enzyme exposure in the British baking industry. Ann Occup Hyg 2006;50:379-84.

25. Sarlo K, Fletcher ER, Gaines WG, et al. Respiratory allergenicity of detergent enzymes in the guinea pig intratracheal test: association with sensitization of occupationally exposed individuals. Fundam Appl Toxicol 1997;39:44-52.

26. Houba R, Heederik DJ, Doekes G, et al. Exposure-sensitization relationship for alphaamylase allergens in the baking industry. Am J Respir Crit Care Med 1996;154:130-6.

27. Fishwick D, Barber CM, Bradshaw LM, et al. British Thoracic Society Standards of Care Subcommittee Guidelines on Occupational Asthma. Standards of care for occupational asthma. Thorax 2008;63:240-50.

28. Tarlo SM. Standards of care for occupational asthma. Thorax 2008;63:190-2.

29. Health Council of the Netherlands. Prevention of work-related airway allergies. Recommended occupational exposure limits and periodic screening. The Hague: Health Council of the Netherlands, 2008; publication no. 2008/03E.

30. Malo JL, Gautrin D. From asthma in the workplace to occupational asthma. Lancet 2007:370:295-7.

\section{Keep up to date: sign up for our alerting services}

Find out automatically when an article is published on a specific topic or by a particular author. We can also alert you when an article is cited or if an eLetter or correction is published. You can also choose to be alerted when a new issue is published online [and when we post articles Online First]. Check out the New Content Alerts and Citation tracker from the Online tools section on the home page. 